\title{
Retraction Note to: Artificial neural networks for prediction Charpy impact energy of Al6061/SiCp-laminated nanocomposites
}

\author{
Ali Nazari ${ }^{1}$ - Vahid Reza Abdinejad ${ }^{1}$
}

Published online: 9 October 2020

(c) Springer-Verlag London Ltd., part of Springer Nature 2020

\section{Retraction to: Neural Comput \& Applic (2013) 23:801-813 https://doi.org/10.1007/s00521-012-0996-0}

The Editor-in-Chief has retracted this article [1] because it significantly overlaps with a number of articles including those that were under consideration at the same time [2-4] and previously published articles [5, 6]. Additionally, the article shows evidence of peer review manipulation. The authors have not responded to any correspondence regarding this retraction.

\section{References}

1. Nazari A, Abdinejad VR (2013) Artificial neural networks for prediction Charpy impact energy of A16061/SiCp-laminated nanocomposites. Neural Comput Appl 23:801-813. https://doi. org/10.1007/s00521-012-0996-0
2. Riahi S, Nazari A (2019) RETRACTED ARTICLE: predicting the effects of nanoparticles on early age compressive strength of ashbased geopolymers by artificial neural networks. Neural Comput Appl 31:743-750. https://doi.org/10.1007/s00521-012-1085-0

3. Nazari A, Hajiallahyari H, Rahimi A et al (2019) RETRACTED ARTICLE: prediction compressive strength of Portland cementbased geopolymers by artificial neural networks. Neural Comput Appl 31:733-741. https://doi.org/10.1007/s00521-012-1082-3

4. Nazari A (2013) Analytical modeling of tensile strength of functionally graded steels. Neural Comput Appl 23:787-799. https://doi.org/10.1007/s00521-012-0995-1

5. Nazari A, Sedghi A, Didehvar N (2012) RETRACTED: modeling impact resistance of aluminum-epoxy-laminated composites by artificial neural networks. J Compos Mater 46(13):1593-1605. https://doi.org/10.1177/0021998311421222

6. Nazari A (2013) Artificial neural networks application to predict the compressive damage of lightweight geopolymer. Neural Comput Appl 23:507-518. https://doi.org/10.1007/s00521-0120945-y

Publisher's Note Springer Nature remains neutral with regard to jurisdictional claims in published maps and institutional affiliations.
The original article can be found online at https:// doi.org/10.1007/s00521-012-0996-0.

\section{Ali Nazari}

alinazari84@aut.ac.ir

1 Department of Materials Science and Engineering, Saveh Branch, Islamic Azad University, Saveh, Iran 